\title{
Perbandingan Kemampuan Representasi Matematis Siswa antara Contextual Teaching and Learning dan Problem Based Learning
}

\author{
Risda Damayanti ${ }^{1}$, Ekasatya Aldila Afriansyah ${ }^{2 *}$ \\ ${ }^{1}$ Pendidikan Matematika, SD Negeri Parakan 1, Kp. Parakan, RT/RW 2/7, \\ Dsn/Ds/Kel. Parakan, Kec. Samarang, Kab. Garut, Jawa Barat, Indonesia. \\ ${ }^{2}$ Program Studi Pendidikan Matematika, Institut Pendidikan Indonesia, \\ Jl. Pahlawan No. 32 Sukagalih, Garut, Jawa Barat, Indonesia. \\ *E-mail : ekafrian@institutpendidikan.ac.id
}

Article received: 04-07-2018, article revised :04-09-2018, article published: 07-09-2018

DOI : 10.25273/jipm.v7i1.3078

\begin{abstract}
Abstrak
Tujuan penelitian ini adalah untuk mengetahui perbandingan dan peningkatan kemampuan representasi matematis siswa terhadap model pembelajaran CTL dan PBL. Metode penelitian yang digunakan adalah quasi experiment dengan pengambilan sampel purposive sampling. Sampel penelitian dipilih dua kelas dari kelas XI MIPA SMAN 17 Garut tahun ajaran 2017/2018. Kelas eksperimen I yaitu kelas XI MIPA 1 yang mendapatkan model pembelajaran CTL sebanyak 20 siswa, dan kelas eksperimen II yaitu kelas XI MIPA 3 yang mendapatkan model pembelajaran $P B L$ sebanyak 20 siswa. Hasil dari penelitian ini dapat disimpulkan bahwa kemampuan representasi matematis siswa dengan menggunakan model pembelajaran $C T L$ lebih baik dibandingkan dengan siswa yang mendapatkan model pembelajaran $P B L$. Sementara itu, untuk peningkatan kemampuan representasi matematis siswa yang mendapatkan model pembelajaran Contextual Teaching and Learning berinterpretasi tinggi dan Problem Based Learning berinterpretasi sedang. Serta secara umum sikap siswa terhadap pembelajaran matematika dengan menggunakan model pembelajaran Contextual Teaching and Learning dan Problem Based Learning masing-masing berinterpretasi baik.
\end{abstract}

Kata Kunci : Kemampuan Representasi Matematis, Contextual Teaching and Learning, Problem Based Learning, quasi eksperimen.

\section{Comparating Students' Mathematical Representative Skills between Contextual Teachingand Learningand Problem Based Learning}

\begin{abstract}
The objective of this research is to find out the comparison and the raising of the students' ability to the mathematical representation toward $C T L$ and $P B L$ learning method. The research method used in this research is quasi experiment and purposive sampling is the technique of sampling. The sample of data is chosen from two classes of XI MIPA SMAN17 Garut, period 2017/2018. The first class is XI MIPA 1 which getting the CTL learning method at the rate of 20 students, and the second class is XI MIPA 3 which getting $P B L$ learning method to the number of 20 students. The finding of this research is the ability of students' mathematical representation using CTL learning method better than the $P B L$ students. Meanwhile, the raising ability of students' mathematical representation which getting Contextual Teaching and Learning method indicates high-ranked and the Problem Based Learning shows medium. Generally, the student attitudes toward math learning using the Contextual Teaching and Learning and Problem Based Learning method are good.
\end{abstract}

Keywords : The Ability of Mathematical Representation, Contextual Teaching and Learning, Problem Based Learning, quasi experiment. 


\section{JIPM (Jurnal Ilmiah Pendidikan Matematika), 7(1), September 2018 - 31}

Risda Damayanti, Ekasatya Aldila Afriansyah

\section{PENDAHULUAN}

Matematika adalah salah satu mata pelajaran yang dianggap sulit oleh siswa karena objeknya yang bersifat abstrak. Di kelas, siswa merasa sulit memberikan alasan atas jawaban mereka, rasa takut keliru dalam menjawab pertanyaan, dan malu menyampaikan pendapat (Afriansyah, 2017a).

Menurut NCTM (2000), "Terdapat lima kemampuan dasar matematika yang merupakan standar, yaitu pemecahan masalah (problem solving), penalaran dan pembuktian (reasoning and proof), komunikasi (communication), koneksi (connection), dan representasi (representation)".

Sejalan dengan yang dikatakan Afriansyah (2017b), seseorang harus memilih kemampuan dalam menyelesaikan permasalahan. Kompetensi tersebut diperlukan agar siswa dapat memiliki kemampuan memperoleh, mengelola, dan memanfaatkan informasi untuk bertahan hidup pada keadaan yang selalu berubah, tidak pasti, dan kompetitif.

Setiap kemampuan matematis tersebut termasuk pada berpikir tingkat tinggi yang harus dikembangkan dalam proses pembelajaran matematika. Setiap aspek dalam berpikir matematik tingkat tinggi mempunyai ruang lingkup yang sangat luas, sehingga agar tidak melebardalam penelitian ini yang akan diukur hanya kemampuan representasi matematis siswa.

Jones (Narulita, 2013) berpendapat ada beberapa alasan perlunya representasi, yaitu: "Memberi kelancaran siswa dalam membangun suatu konsep dan berpikir matematik serta memiliki kemampuan dan pemahaman konsep yang kuat dan fleksibel yang di bangun oleh guru melalui representasi matematis".

Representasi matematis merupakan salah satu kemampuan matematis yang masih jarang diterapkan dalam kegiatan pembelajaran matematika, padahal representasi matematis dapat membantu dalam meningkatkan motivasi siswa. Beberapa peneliti telah mengungkapkan hasil penelitiannya mengenai kemampuan representasi. Ada berbagai macam model pembelajaran yang dapat digunakan untuk melihat kemampuan representasi matematis siswa

Model pembelajaran yang dibutuhkan sekarang tidak semata-mata dikembangkan dari buku ajar tetapi lebih menekankan pada konteks lingkungan kehidupan sehari-hari, baik lingkungan fisik, kehidupan sosial, ekonomi maupun psikologis dan keterpaduan antar materi pembelajaran (Komalasari, 2011).

Saat ini terdapat berbagai model pembelajaran yang dikembangkan dalam bidang pendidikan khususnya dalam bidang matematika. Dalam hal ini,terdapat dua model pembelajaran yang digunakan dalam penelitian ini yaitu model pembelajaran Contextual Teaching and Learning dan model pembelajaran Problem Based Learning. Keduanya diharapkan dapat membantu meningkatkan motivasi belajar dan kemampuan representasi matematis yang dimiliki siswa.

Contextual Teaching and Learning merupakan model pembelajaran yang mengaitkan materi pelajaran dengan situasi dunia nyata. Situasi dunia nyata ini di dalam CTL dipaparkan dalam bentuk persoalan/ pertanyaan cerita. Pertanyaan cerita ini memiliti kesulitan tersendiri bagi siswa (Hoogland, de Koning, Bakker, Pepin, \& Gravemeijer, 2018), akan tetapi pertanyaan matematik dalam bentuk cerita ini dapat membantu siswa memahami kaitan antara materi pelajaran dengan situasi dunia nyatakarena bersifat kontekstual. Persoalan kontekstual dapat menciptakan pembelajaran yang "meaningful"(Kostiainen et al., 2018). Beberapa penelitian terkini telah menggunakan model pembelajaran $C T L$ ini dan $C T L$ ini terbukti dapat meningkatkan beberapa variabel kemampuan matematis, yaitu: kemampuan berpikir kritis (Syahbana, 2011); kemampuan representasi matematis (Hutagaol, 2013; I Widiati, 2015); dan kemampuan penalaran statistis matematis (Maryati, 2017).

Sedangkan Problem Based Learning merupakan sebuah model yang 
mengedepankan sebuah masalah yang harus dipecahkan oleh siswa dengan konsep atau pengetahuan yang mereka miliki. Dalam penelitian Loyens, Jones, Mikkers, \& van Gog(2015), diperoleh bahwa penerapan $P B L$ dalam pembelajaran di sekolah dapat meningkatkan pemahaman konseptual siswa jika dibandingkan dengan pembelajaran ceramah oleh guru atau siswa belajar sendiri. Beberapa penelitian relevan telah menggunakan model pembelajaran $P B L$ ini terbukti dapat meningkatkan beberapa variabel kemampuan matematis, yaitu: kemampuan pemahaman matematis (Alan \& Afriansyah, 2017; Muhson, 2009); kemampuan komunikasi matematis (Alamiah \& Afriansyah, 2017; Fatimah, 2012); kemampuan pemecahan masalah matematis (Fatimah, 2012; Nadhifah \& Afriansyah, 2016); kemampuan berpikir kreatif (Khoiri, Rochmad, \& Cahyono, 2013); kemampuan representasi matematis (Farhan \& Retnawati, 2014).

Rumusan masalah pada penelitian ini yaitu: 1) Apakah kemampuan representasi matematis siswa yang mendapat model pembelajaran $C T L$ lebih baik dibandingkan dengan siswa yang mendapatkan model pembelajaran $P B L, 2$ ) Bagaimana peningkatan kemampuan representasi matematis siswa yang mendapat model pembelajaran $C T L, 3)$ Bagaimana peningkatan kemampuan representasi matematis siswa yang mendapat model pembelajaran $P B L$.

Secara umum, representasi dapat diartikan sebagai mengungkapkan kembali ide atau gagasan melalui gambar, objek, katakata ataupun symbol. Aditya (2014) mengatakan, dalam psikologi umum representasi berarti proses membuat model konkret dalam dunia nyata ke dalam konsep abstrak atau simbol.

Lestari \& Yudhanegara (2015) mengatakan bahwa indikator kemampuan representasi adalah sebagai berikut: 1) Menyajikan kembali data dari suatu representasi ke representasi diagram, grafik, atau tabel; 2) Menggunakan representasi visual untuk menyelesaikan masalah; 3) Membuat pola- pola geometri; 4) Membuat gambar bangun geometri untuk memperjelas masalah dan memfasilitasi penyelesaian; 5) Membuat persamaan atau model matematis dari representasi lain yang diberikan; 6) Membuat konjektur dari suatu pola bilangan; 7) Penyelesaian masalah dengan melibatkan ekspresi matematis siswa; 8) Membuat situasi masalah berdasarkan data atau representasi yang diberikan; 9) Menulis interpretasi dari suatu representasi; 10) Menulis langkahlangkah penyelesaian masalah matematis dengan kata-kata; 11) Menjawab soal dengan menggunakan kata-kata atau teks tertulis

Dimana semua kemampuan tersebut terbagi kedalam empat aspek yaitu, representasi visual, gambar, persamaan atau ekspresi matematis dan representasi kata atau teks tulis.

Sementara itu, pembelajaran kontekstual adalah usaha untuk membuat siswa aktif dalam memompa kemampuan diri tanpa merugi dari segi manfaat, sebab siswa berusaha mempelajari konsep sekaligus menerapkan dan mengaitkannya dengan dunia nyata (Rusman, 2012). Pembelajaran ini pun merupakan suatu pembelajaran yang sudah sangat dikenal banyak praktisi di bidang pendidikan dan sering digunakan dengan maksud ingin menekankan pada situasi sebenarnya dengan bantuan informasi/persoalan kontekstual. Persoalan kontekstual ini diharapkan dapat menggiring siswa untuk memperoleh gambaran ide/model pembelajaran yang sesuai dengan situasi/persoalan yang diberikan (Pereira \& Papa, 2016). Menurut Anh (2017), seorang guru harus melihat persoalan kontekstual ini sebagai "teman bicara" di dalam pengembangan pengetahuannya.

Langkah-Langkah model pembelajaran CTL Menurut Lestari \& Yudhanegara (2015), adalah : 1) Grouping; 2) Modelling; 3) Questioning; 4) Learning community; 5) Inquiry; 6) Contructivisme; 7) Authentic assessment; 8) Reflection.

Barret (Lidinillah \& Abdul, 2009) mengemukakan bahwa $P B L$ untuk pertama 
kalinya diterapkan pada sekolah kedokteran di perguruan tinggi "McMaster University" Kanada pada sekitar tahun 60-an. $P B L$ diterapkan sebagai sebuah pendekatan pembelajaran pada sekolah kedokteran dengan alasan karena $P B L$ dianggap sangat efektif dalam sekolah kedokteran dimana mahasiswa dihadapkan pada permasalahan terlebih dahulu kemudian dituntut untuk memecahkan masalah tersebut.

Langkah-langkah $P B L$ menurut Heriawan dkk. (2012) adalah sebagai berikut: a) Orientasi siswa pada masalah; b) Mengorganisasi siswa untuk belajar; c) Membimbing penyelidikan individual maupun kelompok; d) Mengembangkan dan menyajikan hasil karya; e) Menganalisis dan mengevaluasi proses pemecahan masalah

Melalui Penerapan kedua model pembelajaran ini diharapkan siswa memiliki keaktifan dan kreativitas dalam proses belajar mengajar sehinga dapat memahami konsep matematika yang diajarkan dengan baik, dan diharapkan bias meningkatkan kemampuan representasi matematis siswa.

\section{METODE}

Metode penelitian yang digunakan dalam penelitian ini adalah metode kuasi eksperimen dengan desain menurut Lestari \& Yudhanegara (2015). Kuasi eksperimen hampir sama dengan eksperimen sebenarnya, perbedaannya terletak pada penggunaan subjek yaitu tidak dilakukan penugasan random, melainkan dengan menggunakan kelompok yang sudah ada. Kelompok dalam suatu kelas biasanya sudah seimbang, sehingga apabila peneliti membentuk kelompok baru tentunya akan menyebabkan rusaknya suasana kealamiahan kelas tersebut.

Dalam penelitian ini, peneliti mengambil populasi penelitian yaitu kelas XI SMAN 17 Garut tahun ajaran 2017/2018. Sedangkan sampel penelitian diambil dua kelas secara acak dari 6 kelas yang ada yang diberikan oleh guru pamong, dua kelas yang diberikan yaitu kelas XI MIPA 1 dan XI MIPA 3. Disini penyusun menyiapkan dua gulungan kertas yang berisikan model pembelajaran $C T L$ dan $P B L$, lalu ketua kelas dari dua kelas tersebut mengambil gulungan tersebut dan diperoleh kelas XI MIPA 1 sebagai kelas yang menggunakan model pembelajaran $C T L$ dengan jumlah siswa sebanyak 20 orang dan kelas XI MIPA 3 sebagai kelas yang menggunakan model pembelajaran $P B L$ dengan jumlah siswa 20 orang.

Adapun teknik pengumpulan data dan instrumen penelitian yang digunakan adalah sebagai berikut: 1) Teknik pengumpulan data berupa tes tulis dan angket; 2) Istrumen penelitian berupa soal uraian (essay) dan skala likert

Kedua kelas tersebut terlebih dahulu diberikan tes awal, yang bertujuan untuk mengetahui kemampuan awal dari masingmasing kelas, setelah melaksanakan beberapa kali proses pembelajaran dengan model pembelajaran yang berbeda, kemudian kedua kelas tersebut diberikan tes akhir dan angket.

Adapun waktu penelitiannya adalah mulai tanggal 4 Januari 2018 sampai dengan tanggal 01 Februari 2018. Yang bertempat di salah satu SMAN di Garut yaitu SMAN 17 Garut

\section{HASIL DAN PEMBAHASAN}

Dari hasil penelitian dengan memberikan perlakuan kepada kedua kelas yaitu kelas XI-MIPA 1 sebagai kelas eksperimen 1 dengan menggunakan model pembelajaran Contextual Teaching and Learning dan kelas XI-MIPA 3 sebagai kelas eksperimen 2 dengan menggunakan model pembelajaran Problem Based Learning dimana kedua kelas eksperimen ini memiliki jumlah objek yang sama yaitu 20 siswa serta keduanya diberi tes awal dan tes akhir, sehingga diperoleh hasil seperti pada tabel 1 dan tabel 2 berikut: 
Tabel 1. Data kelas $C T L$

\begin{tabular}{cccc}
\hline Kelas & \multicolumn{3}{c}{ Contextual Teaching and Learning } \\
\hline Tes & Pretest & Posttest & $\begin{array}{c}\text { Gain Ternor- } \\
\text { malisasi }\end{array}$ \\
\hline $\begin{array}{c}\text { Jumlah } \\
\text { Siswa }\end{array}$ & 20 & 20 & 20 \\
\hline Rata-rata & 9,40 & 32,65 & 0,77 \\
\hline $\begin{array}{c}\text { Deviasi } \\
\text { Standar }\end{array}$ & 4,16 & 3,07 & 0,08 \\
\hline
\end{tabular}

Tabel 2. Data kelas $P B L$

\begin{tabular}{cccc}
\hline Kelas & \multicolumn{3}{c}{ Problem Based Learning } \\
\hline Tes & Pretest & Posttest & $\begin{array}{c}\text { Gain Ternormal- } \\
\text { isasi }\end{array}$ \\
\hline $\begin{array}{c}\text { Jumlah } \\
\text { Siswa }\end{array}$ & 20 & 20 & 20 \\
\hline Rata-rata & 7,55 & 27,85 & 0.65 \\
\hline $\begin{array}{c}\text { Deviasi } \\
\text { Standar }\end{array}$ & 5,104 & 9,94 & 0,25 \\
\hline
\end{tabular}

Dari tabel 1 dan 2, terlihat bahwa deviasi standar Pretest maupun Posttest kelas Contextual Teaching and Learning lebih rendah dari pada kelas Problem Based Learning, hal tersebut menunjukan bahwa kemampuan reresentasi matematis kelas Contextual Teaching and Learning lebih menyebar. Sedangkan berdasarkan peningkatan dari kedua kelasContextual Teaching and Learningdan Problem Based Learningyang di analisis dengan uji Gain Ternormalisasi diperoleh masing-masing rata-ratanya 0,77 dan 0,65, maka untuk kelas Contextual Teaching and learning berinterpretasi tinggi, sedangkan kelas Problem Based Learning berinterpretasi sedang. Serta secara umum sikap siswa terhadap pembelajaran matematika dengan menggunakan model pembelajaran Contextual Teaching and Learningdan Problem Based Learning masing-masing berinterpretasi baik.

Untuk tes awal dilakukan uji normalitas terlebih dahulu, dan diketahui untuk kedua kelas tersebut berdistribusi normal. Kemudian dilanjutkan dengan uji homogenitas dan diketahui hasilnya adalah $F_{\text {hitung }}=$ $1,503<\mathrm{F}_{\text {tabel }}=2,170$ maka kedua varian homogen, karena variansnya homogen maka dilanjutkan dengan uji t, tetapi sebelum melakukan perhitungan uji $\mathrm{t}$ disinipeneliti merumuskan terlebih dahulu hipotesis nol dan hipotesis alternatifnya, yaitu:

$\mathrm{H}_{\mathrm{o}}$ : Tidak terdapat perbedaan yang signifikan antara kemampuan awal siswa kelas Contextual Teaching and Learning dan kemampuan awal siswa kelas Problem Based Learning.

$\mathrm{H}_{\mathrm{a}}$ : Terdapat perbedaan yang signifikan antara kemampuan awal siswa kelas Contextual Teaching and Learning dan kemampuan awal siswa kelas Problem Based Learning.

Setelah melakukan perhitungan dengan uji dua pihak, diperoleh nilai Karena nilai $\mathrm{t}_{\text {tabel }}=-2,025<\mathrm{t}_{\text {hitung }}=1,257<\mathrm{t}_{\text {tabel }}=$ 2,025 dengan demikian $\mathrm{H}_{\mathrm{o}}$ diterima, maka dapat disimpulkan bahwa tidak terdapat perbedaan yang signifikan antara kemampuan awal siswa kelas Contextual Teaching and Learning dan kemampuan awal siswa kelas Problem Based Learning

Setelah dilakukan pembelajaran maka didapatkan hasil tes akhir, untuk data yang didapat dari kedua kelas maka dialakukan uji normalitas dan diketahui hasil yang didapat kedua kelas berdistribus normal. Langkah selanjutnya dilakukan pengujian homogenitas yang disjelaskan dalam tabel 3 berikut:

Tabel 3. Data Uji Homogenitas Dua Varians

\begin{tabular}{cccc}
\hline Kelas & \multicolumn{2}{c}{$\mathbf{F}$} & Kriteria \\
\cline { 2 - 3 } & $\mathrm{F}_{\text {hitung }}$ & $\mathrm{F}_{\text {tabel }}$ & \\
\hline Contextual & & & \\
$\begin{array}{c}\text { Teaching and } \\
\text { Learning }\end{array}$ & & & Tidak \\
$\begin{array}{c}\text { Problem Based } \\
\text { Learning }\end{array}$ & & 2,170 & Homogen \\
\hline
\end{tabular}

Dari tabel 4 diketahui bahwa $F_{\text {hitung }}=$ $10,483>\mathrm{F}_{\text {tabel }}=2,170$ maka kedua varian tidak homogen. Karena kedua varians tidak homogen maka menguji kesamaan dua ratarata kemampuan akhir siswa adalah dengan uji $t$.

Sebelum melakukan perhitungan, peneliti merumuskan terlebih dahulu hipotesis nol dan hipotesis alternatifnya, yaitu: 
$\mathrm{H}_{\mathrm{o}}$ : Kemampuan representasi matematis siswa yang mendapatkan model pembelajaran Contextual Taeaching and Learning tidak lebih baik dibandingkan siswa yang mendapatkan model pembelajaran Problem Based Learning.

$\mathrm{H}_{\mathrm{a}}$ : Kemampuan representais matematis siswa yang mendapatkan model pembelajaran Contextual Teaching and Learning lebih baik dibandingkan siswa yang mendapatkan model pembelajaran Problem Based Learning.

Setelah melakukan perhitungan, diperoleh nilai $t^{\circ}=2,06>\frac{w_{1} t_{1}+w_{2} t_{2}}{w_{1}+w_{2}}=1,73$, sehingga $\mathrm{H}_{\mathrm{o}}$ ditolak. Dengan demikian dapat disimpulkan bahwa kemampuan representasi matematis siswa yang mendapatkan model pembelajaran Contextual Teaching and Learning lebih baik dibandingkan siswa yang mendapatkan model pembelajaran Problem Based Learning.

Dilihat dari hasil posttest, dari kualitas peningkatannya, dari skala sikap yang telah diolah, sangat jelas terlihat bahwa kelas Contextual Teaching and Learning lebih baik dibandingkan kelas Problem Based Learning

Dari hasil analisis dapat disimpulkan bahwa kemampuan representasi matematis siswa yang menggunakan model pembelajaran Contextual Teaching and Learning lebih baik kemampuan representasi matematisnya dibandingkan siswa yang mendapatkan model pembelajaran Problem Based Learning. Tetapi meskipun dari hasil prettest, posttest, kualitas peningkatan, dan sikap siswa kelas Contextual Teaching and Learning lebih dominan dari kelas Problem Based Learning, tetapi pada dasarnya dari kedua kelas telah terjadi peningkatan kualitas belajar. Hasil peningkatan kemampuan representasi matematis dengan kedua model dapat dilihat pada gambar 1 .

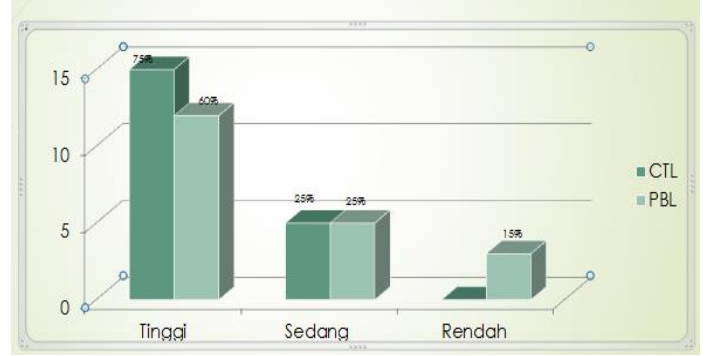

Gambar 1. Persentase Peningkatan Kemampuan Representasi

Dalam proses pembelajaran yang dilaksanakan selama lima kali pertemuan untuk kelas Contextual Teaching and Learning dan kelas Problem Based Learning, kedua kelas tersebut bisa mengikuti proses pembelajaran dengan baik. Hal tersebut dapat dilihat dari hasil angket pada tabel 4 bahwa kedua kelas tersebut menunjukan sikap yang baik terhadap pembelajaran matematika dan juga terhadap soal-soal representasi matematis yang diberikan. Meski kedua kelas memiliki sikap dengan interpretasi baik tetapi hasil yan ditemukan kelas Contextual Teaching and Learning lebih baik dibandingkan kelas Problem Based Learning, hal ini disebabkan karena pada kelas Problem Based Learning terdapat pertemuan dengan jam pelajaran di akhir pembelajarandan pada siang hari yang mana konsentrasi siswa sudah tidak $100 \%$ terfokus kedalam proses pembelajaran.

Tabel 4. Sikap Siswa Secara Keseluruhan

\begin{tabular}{llccc}
\hline Kelas & \multicolumn{1}{c}{ Aspek } & Jumlah & Total & Ket \\
\hline$C T L$ & Pelajaran & 678 & & \\
& matematika & 539 & 1740 & Baik \\
& $\begin{array}{l}\text { Model } \\
\text { Soal-soal }\end{array}$ & 523 & & \\
& Pemecahan & & & \\
\hline$P B L$ & Pelajaran & 665 & & \\
& matematika & 579 & 1824 & Baik \\
& $\begin{array}{l}\text { model } \\
\text { Soal-soal }\end{array}$ & 580 & & \\
\hline & Pemecahan & & & \\
\hline
\end{tabular}

Hasil yang diperoleh dari penelitian ini senada dengan penelitian Hutagaol (2013) dan Widiati (2015), yang menyatakan bahwa kemampuan representasi matematis siswa meningkat ketika diberikan pembelajaran 
dengan menggunakan model pembelajaran kontekstual $(C T L)$.

Pada proses pembelajaran, peneliti menemukan beberapa kelebihan dan kekurangan terhadap model pembelajaran $C T L$ yang diterapkan pada kelas eksperimen 1. Kelebihannya yaitu: 1) Siswa memiliki rasa sosial yang tinggi karena mereka belajar secara berkelompok; 2) Adanya masyarakat belajar, sehingga membuat siswa saling tolong menolong. Bagi siswa yang lebih paham terhadap materi pembelajaran, siswa tersebut membantu anggota kelompoknya yang belum memahami materi. Hal tersebut bisa membuat siswa mendapatkan kesimpulan dari pembelajaran secara sempurna; 3) Siswa mempresentasikan hasil temuannya di depan kelas, sehingga membuat mereka lebih percaya diri untuk tampil di depan banyak orang; 4) Menumbuhkan keberanian siswa dalam mengungkapkan pendapatnya terhadap materi pembelajaran; 5) Siswa mampu membuat kesimpulan dari materi pembelajaran yang mereka diskusikan; 6) Siswa lebih memahami materi karena soalsoal yang dihadirkan bersangkutan dengan kehidupan mereka sehari-hari, hal ini pun membuat siswa belajar lebih nyaman.

Dalam proses pembelajaran, ketika ada kelebihan pun pasti terdapat kekurangan. Adapun kekurangannya yaitu: 1) Masih terdapat siswa yang mengobrol di luar materi pembelajaran selama proses diskusi berlangsung; 2) Terdapat siswa yang hanya mengandalkan anggota kelompoknya dan siswa tersebut tidak mau berusaha; 3) Siswa merasa bosan dengan model pembelajaran yang sama selama penelitian berlangsung sehingga membuat pembelajaran tidak kondusif; 4) Siswa masih merasa kesulitan dalam membangun pemahamannyan sendiri.

Senada dengan penelitian (Farhan \& Retnawati, 2014) ditemukan bahwa $P B L$ dan $I B L$ lebih efektif dibandingkan dengan pembelajaran konvensional dan $P B L$ lebih efektif dibandingkan dengan $I B L$. Sedangkan dalam penelitian yang peneliti lakukan ditemukan bahwa $P B L$ dapat meningkatkan kemampuan representasi ma- tematis tetapi tidak lebih baik jika dibandingkan dengan model pembelajaran CTL.

Terdapat kelebihan selama proses pembelajaran dengan menggunakan model pembelajaran $P B L$ berlangsung, yaitu: 1) Menumbuhkan sikap sosial dalam kegiatan kelompok; 2) Menantang kemampuan siswa untuk menemukan pengetahuan baru bagi siswa; 3) Siswa lebih aktif dalam belajar; 4) Menumbuhkan kepercayaan diri siswa dalam mempresentaskan hasil temuannya.

Adapun kelamahan yang peneliti temukan yaitu sebagai berikut: 1) Mereka enggan menyelesaikan permasalahan ketika masalah tersebut membuat mereka merasa kebingungan; 2) Terdapat banyak siswa yang beralasan ijin keluar untuk ke kamar kecil karena merasa bosan; 3) Mereka mengeluh karena harus terus melakukan hal yang sama disetiap pembelajaran sehingga membuat mereka malas dalam mengikuti pemelajarn; 4) Terdapat siswa yang hanya mengandalkan teman yang lebih pintar tanpa mau berusaha terlebih dahulu.

Dokumentasi pada saat kegiatan pembelajaran berlangsung bisa dilihat pada gambar 2 dan 3.

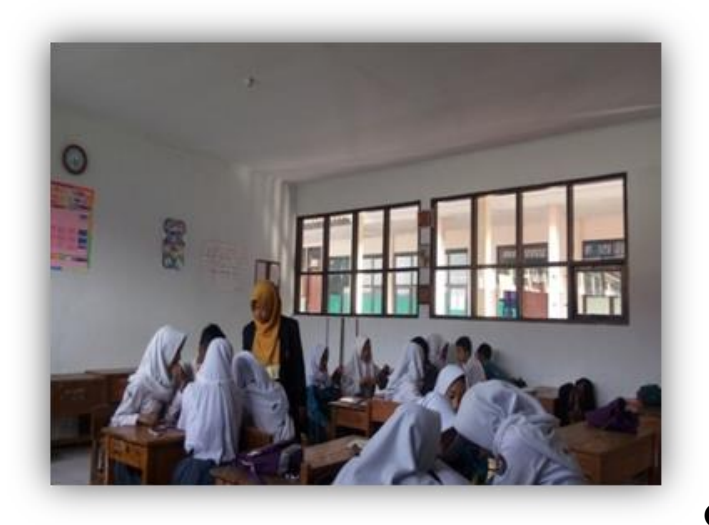

mbar 2. Kegiatan pembelajaran di kelas Ga Contextual Teaching and Learning 


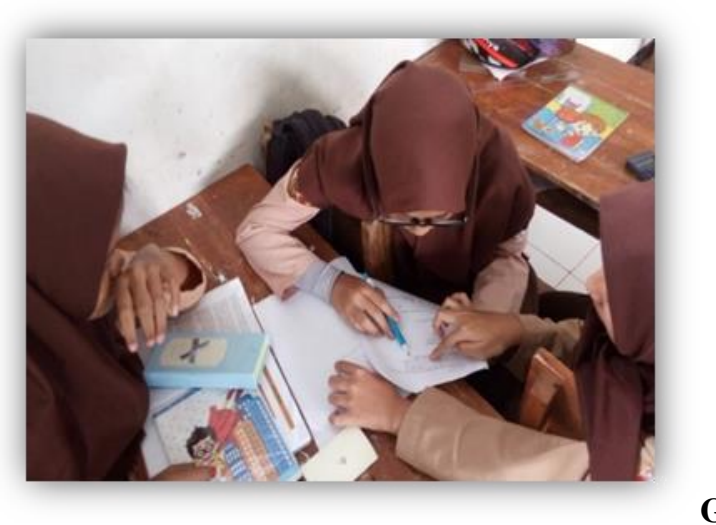

ambar 3. Kegiatan Pembelajaran di Kelas Problem Based Learning

Dari hasil pengamatan peneliti selama pelaksanaan penelitian berlangsung, ada beberapa penyebab $C T L$ lebih baik dari $P B L$. Dalam hal ini adanya perbedaan sebagai berikut:

1. Kedua kelas bekerja dalam kegiatan kelompok, keduanya berusaha menemukan konsep pembelajaran sendiri dengan mencari sumber dan berdiskusi, keduanya pun mendapatkan bimbingan dari guru dalam proses tersebut tetapi soal dalam LAS yang diberikan kepada kedua kelas tersebut berbeda, yaitu kelas CTL mendapatkan soal-soal kontekstual atau soal-soal sehari-hari sehingga mereka lebih semangat dan lebih asyik dalam menyelesaikan soal-soal yang diberikan. Sedangkan kelas kedua yaitu kelas $P B L$ mendapatkan soal-soal yang bermasalah yang lebih kompleks sehingga membuat mereka lebih berpikir keras dan banyak dari mereka yang akhirnya malas mengerjakan jika tidak ada bimbingan dari guru.

2. Meski kedua sikap nya sama-sama baik, dan menghasilkan salah satu lebih baik, ini disebabkan karena pada kelas CTL banyak siswa yang memiliki minat dan semangat tinggi serta sudah belajar dengan maksimal tetapi hasil akhir yang di dapat tetap sama saja. Fenomena ini banyak terjadi dalam dunia pendidikan di negara kita, solusinya siswa tersebut harus mendapatkan perlakuan berbeda dan lebih banyak diberi latihan agar bisa membantu mempercepat dan memperkuat proses berpikir mereka.
3. Setiap siswa pada kelas $C T L$ berusaha untuk bisa bekerjasama dalam menyelesaikan LAS. Sedangkan pada kelas $P B L$, terdapat anggota kelompok yang hanya mengandalkan anggota yang lebih memahami materi agar bisa menyelesaikan permasalahan yang didapatnya.

4. Terdapat proses pembelajaran yang tidak kondusif pada kelas $P B L$ karena terjadwal pada hari jumat di jam terakhir. Sedangkan kelas $C T L$ mendapatkan jadwal pembelajaran pada pagi hari di kedua pertemuan setiap minggunya.

\section{SIMPULAN}

Berdasarkan hasil analisis data dan pembahasan secara keseluruhan terhadap data penelitian mengenai perbandingan kemampuan representasi matematis siswa antara yang mendapatkan model pembelajaran Contextual Teaching and Learning dan Problem Based Learning yang dilakukan di SMAN 17 Garut, maka sesuai dengan rumusan masalah, peneliti memperoleh simpulan sebagai berikut, kemampuan representasi matematis siswa yang mendapatkan model pembelajaran Contextual Teaching and Learning lebih baik dibandingkan siswa yang mendapatkan model pembelajaran Problem Based Learning. Sementara itu, untuk peningkatan kemampuan representasi matematis siswa yang mendapatkan model pembelajaran Contextual Teaching and Learning berinterpretasi tinggi dan Problem Based Learning berinterpretasi sedang. Serta secara umum sikap siswa terhadap pembelajaran matematika dengan menggunakan model pembelajaran Contextual Teaching and Learning dan Problem Based Learning masing-masing berinterpretasi baik.

Peneliti menyadari sepenuhnya bahwa dalam penelitian ini masih banyak kekurangan. Namun demikian, hasil penelitian diharapkan dapat memberikan referensi serta sumbangan ilmu pengetahuan yang berarti dalam dunia pembelajaran guna untuk meningkatkan kualitas belajar matematika siswa. Berdasarkan temuan penelitian, 
peneliti menyarankan guru untuk menggunakan model pembelajaran Contextual Teaching and Learning dan Problem Based Learning sebagai salah satu alternatif model pembelajaran yang bisa digunakan di kelas dalam proses belajar mengajar. Serta

\section{DAFTARPUSTAKA}

Aditya, A. (2014). Pendekatan Realistic Mathematics Education untuk Meningkatkan Kemampuan Representasi Matematis Siswa.

Afriansyah, E. A. (2017a). Desain Lintasan Pembelajaran Pecahan Melalui Pendekatan Realistic Mathematics Education. Mosharafa: Jurnal Pendidikan Matematika, 6(3), 463-474. Retrieved from http://e-mosharafa.org/index.php/ mosharafa/article/view/mv6n3_15/137

Afriansyah, E. A. (2017b). Problem Posing Sebagai Kemampuan Matematis. Mosharafa: Jurnal Pendidikan Matematika, 6(1), 163-180. Retrieved from http://e-mosharafa.org/index.php/ mosharafa/article/view/mv6n1_15/pdf_1

Alamiah, U. S., \& Afriansyah, E. A. (2017). Perbandingan Kemampuan Komunikasi Matematis Siswa Antara yang Mencapatkan Model Pembelajaran Problem Based Learning dengan Pendekatan Realistic Mathematics Education dan Open-Ended. Mosharafa: Jurnal Pendidikan Matematika, 6(2), 207-216. Retrieved from http://e-mosharafa.org/ index.php/mosharafa/article/view/mv6 n2_4/93

Alan, U. F., \& Afriansyah, E. A. (2017). Kemampuan Pemahaman Matematis Siswa Melalui Model Pembelajaran Auditory Intelectually Repetition Dan Problem Based Learning. Jurnal Pendidikan Matematika UNSRI, 11(1), 67-78. https://doi.org/10.22342/jpm. 11.1.3890.67-78

Anh, D. T. K. (2017). Exploring contextual factors shaping teacher collaborative learning in a paired-placement. Teaching
Penelitian ini dilakukan pada subjek terbatas, yaitu siswa SMAN 17 Garut Kelas XI MIPA 1 dan XI MIPA 3 dengan pokok bahasan Statistika. Supaya hasil penelitian lebih umum diperlukan penelitian lebih lanjut di sekolah serta materi yang berbeda.

and Teacher Education, 67, 316-329. https://doi.org/10.1016/j.tate.2017.06.008

Farhan, M., \& Retnawati, H. (2014). Keefektifan $P B L$ Dan IBL Ditinjau dari Prestasi Belajar, Kemampuan Representasi Matematis, dan Motivasi Belajar. Jurnal Riset Pendidikan Matematika, 1(2), 227-239. https://doi.org/ 10.21831/jrpm.v1i2.2678

Fatimah, F. (2012). Kemampuan Komunikasi Matematis dan Pemecahan Masalah Melalui Problem Based-Learning. Jurnal Penelitian Dan Evaluasi Pendidikan, 16, 249-259.

Heriawan, A., Darmajari, \& Senjaya, A. (2012). Metodologi Pembelajaran. (S. Iskandar, Ed.). Banten: LP3G.

Hoogland, K., de Koning, J., Bakker, A., Pepin, B. E. U., \& Gravemeijer, K. (2018). Changing representation in contextual mathematical problems from descriptive to depictive: The effect on students' performance. Studies in Educational Evaluation, 58(June), 122-131. https://doi.org/10.1016/j.stu educ. 2018.06.004

Hutagaol, K. (2013). Pembelajaran Kontekstual untuk Meningkatkan Kemampuan Representasi Matematis Siswa Sekolah Menengah Pertama. Jurnal Ilmiah Program Studi Matematika STKIP Siliwangi Bandung, 2(1), 85-99.

Khoiri, W., Rochmad, \& Cahyono, A. N. (2013). Problem Based Learning Berbantuan Multimedia Dalam Pembelajaran matematika Untuk Meningkatkan Kemampuan Berpikir Kreatif. Journal of Mathematics Education, 2(1), 115-121. 
Komalasari, K. (2011). Pembelajaran Kontekstual Konsep dan Aplikasi. Bandung: Refika Aditama.

Kostiainen, E., Ukskoski, T., Ruohotie-Lyhty, M., Kauppinen, M., Kainulainen, J., \& Mäkinen, T. (2018). Meaningful learning in teacher education. Teaching and Teacher Education, 71, 66-77. https:// doi.org/10.1016/j.tate.2017.12.009

Lestari, K. E., \& Yudhanegara, M. R. (2017). Penelitian Pendidikan Matematika. Karawang: Refika Aditama.

Lidinillah, D. abdul M. (2009). Pembelajaran Berbasis Masalah (Problem Based Learning).

Loyens, S. M. M., Jones, S. H., Mikkers, J., \& van Gog, T. (2015). Problem-based learning as a facilitator of conceptual change. Learning and Instruction, 38, 34-42. https://doi.org/10.1016/j. learninstruc.2015.03.002

Maryati, I. (2017). Peningkatan Kemampuan Penalaran Statistis Siswa Sekolah Menengah Pertama Melalui Pembelajaran Kontekstual. Mosharafa: Jurnal Pendidikan Matematika, 6(1), 129140. Retrieved from http://emosharafa.org/index.php/mosharafa/ar ticle/view/mv6n1_12/pdf_1

Muhson, A. (2009). Peningkatan Minat Belajar dan Pemahaman Mahasiswa Melalui Penerapan Problem-Based Learning. Kependidikan, 39(2), 171-182.

Nadhifah, G., \& Afriansyah, E. A. (2016). Peningkatan Kemampuan Pemecahan Masalah Matematis Siswa dengan Menerapkan Model Pembelajaran Problem Based Learning dan Inquiry. Mosharafa: Jurnal Pendidikan Mate- matika, 5(1), 33-44. Retrieved from http://e-mosharafa.org/index.php/ mosharafa/article/view/mv5n1_5/187

Narulita, A. A. (2013). Keefektifan Pembelajaran Model Designed StudentCenteres Instructional terhadap Kemampuan Representasi Peserta Didik Kelas VIII Materi Luas Permukaan Bangun Ruang Sisi Datar. Universitas Negeri Semarang. Retrieved from http://lib.unnes.ac.id/18828/1/4101409 042.pdf

NCTM. (2000). Principles and Standars for School Mathematics. Retrieved from http://www.nctm.org/standards/content .aspx?id=16909

Pereira, D. R., \& Papa, J. P. (2016). A new approach to contextual learning using interval arithmetic and its applications for land-use classification. Pattern Recognition Letters, 83, 188-194. https://doi.org/10.1016/j.patrec.2016.0 3.020

Rusman. (2012). Model-model pembelajaran (mengembangkan profesionalisme guru). Jakarta: Rajagrafindo Persada.

Syahbana, A. (2011). Kemampuan Berpikir Kritis Matematis Siswa SMP Melalui Pendekatan Contextual Teaching and Learning. Edumatica, 2 (April), 45-57.

Widiati, I. (2015). Mengembangkan Kemampuan Representasi Matematis Siswa Sekolah Menengah Pertama Melalui Pembelajaran Kontekstual. Pengajaran MIPA, 20(2), 106-111. https://doi.org/http://dx.doi.org/10.182 69/jpmipa.v20i2.571 